Documento de Trabajo 2017-05

Facultad de Economía y Empresa

Universidad de Zaragoza

Depósito Legal Z-1411-2010. ISSN 2171-6668

\title{
OVER-QUALIFICATION AND DIMENSIONS OF JOB SATISFACTION
}

\author{
Inmaculada García-Mainar \\ Víctor M. Montuenga-Gómez \\ University of Zaragoza, Department of Economic Analysis, Faculty of Economic and \\ Business, C/ Gran Vía 2, 50005 Zaragoza
}

\begin{abstract}
Over-qualification may arise from voluntary decisions of individuals to acquire more qualifications than those required at the job place. In these cases, mismatch may have a role allowing workers to compensate the lack of some other skills, or to gain access to the labour market. Consequently, workers may feel no less satisfied, at least in some domains, than adequately matched workers. The aim of this paper is to analyse the relationship between over-qualification and different domains of job satisfaction in Spain, a country characterised by a strongly segmented labour market with high unemployment level, and a large number of mismatched. Using micro data for a representative sample of Spanish workers, we employ an IV estimation procedure to control for potential endogeneity arising from reverse causation or unobserved heterogeneity. Results obtained provide apparent evidence on that mismatched workers do not necessarily feel less satisfied than adequately matched workers in all domains of job satisfaction.
\end{abstract}

JEL classification: D82, I26, J24, J28, J62

Keywords: over-qualification, domains of job satisfaction, Spain

Acknowledgments: The authors would like to thank participants at the XII Labour Economics Meeting, for helpful comments on earlier drafts of this paper. 


\title{
OVER-QUALIFICATION AND DIMENSIONS OF JOB SATISFACTION
}

\begin{abstract}
Over-qualification may arise from voluntary decisions of individuals to acquire more qualifications than those required at the job place. In these cases, mismatch may have a role allowing workers to compensate the lack of some other skills, or to gain access to the labour market. Consequently, workers may feel no less satisfied, at least in some domains, than adequately matched workers. The aim of this paper is to analyse the relationship between over-qualification and different domains of job satisfaction in Spain, a country characterised by a strongly segmented labour market with high unemployment level, and a large number of mismatched. Using micro data for a representative sample of Spanish workers, we employ an IV estimation procedure to control for potential endogeneity arising from reverse causation or unobserved heterogeneity. Results obtained provide apparent evidence on that mismatched workers do not necessarily feel less satisfied than adequately matched workers in all domains of job satisfaction.
\end{abstract}

JEL classification: D82, I26, J24, J28, J62

Keywords: over-qualification, domains of job satisfaction, Spain 


\section{Introduction}

The generalisation of the phenomenon of over-qualification, which encompasses overeducation, over-experience and skill under-utilisation, follows that of underemployment, a broader concept within which over-qualification is embraced (Feldman, 1996; Johnson et al., 2002). The topic of over-qualification has been extensively studied in the economic literature, with emphasis on the effects on returns and on job satisfaction (see the meta-analyses by Groot and Maassen van den Brink, 2000; Rubb, 2003) and on the phenomena of the bumping down and/or crowding out of less skilled workers (Hartog 2000; Lene, 2011; McGuinness, 2006).

When focusing on the association between over-qualification and job satisfaction a typical finding is a negative relationship, which can be explained under a psychological view by relative deprivation. According to this, when an individual wants an object and feel he/she deserves to get it but do not, that is, when a gap between aspirations and actual realisations exist, he/she becomes frustrated (Crosby 1976, 1984). Wages, responsibilities at job, challenges and career advancements are generally lower for the over-qualified (Bills, 1992; Khan and Morrow, 1991; Maynard and Hakel, 1999; Feldman et al., 2002; Johnson and Johnson, 2000; Johnson et al., 2002) causing a sense of deprivation and unfairness which is reflected in individuals showing lower job performance and more willingness to leave than the adequately matched (Bolino and Feldman, 2000; Feldman et al., 2002; Lee et al., 2016; Tsang et al., 1991; Verhaest and Omey, 2006, 2009). Under this view, firms would prefer hiring adequately qualified job applicants to those who are over-qualified (Bills, 1992; Maynard and Hakel, 1999).

Several findings challenge the relative deprivation theory. First, even though workers may feel unsatisfied because of over-qualification they do not necessarily perform worse than less-qualified, perfectly-matched workers (Holton et al., 2002; Fine and Nevo, 2008; Erdogan and Bauer, 2009). Thus, workers can stay in jobs for which they are over-qualified because these jobs have other good characteristics (McGuinness and Sloane, 2011). Additionally, firms may find over-education useful in assessing the ranking of a particular individual on the ability spectrum (Green et al. 2002), or as an indication of adaptive capacities (Lene 2011).

Second, using wage regressions, it is habitually found that the over-qualified obtain lower wages than equally qualified workers who are in properly matched jobs, but higher wages than less qualified workers in a well-matched job (Groot and Massen van den Brink, 2000; Sloane, 2003; McGuinness, 2006; Leuven and Oosterbeek, 2011; García and Montuenga, 2017). This result suggests that over-qualified are penalised 
against the equally-qualified, properly-matched but extra-rewarded with respect to the well-matched, but less-qualified workers.

In consequence, it is not unsurprising to find studies disclosing the absence of relationship between over-education and job satisfaction (e.g. Groot and Maassen van den Brink, 2000; Büchel, 2002) and even a positive relationship between over-education and firm's productivity (Kampelman and Ryck, 2012). A first explanation for these results is that some determinants may moderate the negative relationship between job satisfaction and over-qualification. Thus, gender, marital status, emotional support or job-related conditions such as empowerment, salary or work experience may alleviate the negative influence of over-qualification on satisfaction (Erdogan and Bauer, 2009; Erdogan et al., 2011; Peiro et al., 2010; Lee et al., 2016). Additionally, given that job satisfaction can be seen as an array of different domains/facets of satisfaction related to performance in the job place, it may be the case that over-qualified workers may feel less satisfied in some domains and more satisfied in others than adequately matched, so that the final component may be of any sign (Johnson and Johnson, 2000; Taber and Alliger, 1995). For example, if workers over-qualify to obtain a permanent position or just to escape from unemployment, then they may report a valuation of satisfaction with job stability or job promotion not very different from that reported by an adequately matched worker, counterbalancing lower valuations corresponding to other domains, such as pay or self-fulfilment.

In this paper, we deepen into this argument by hypothesising that, individuals who over-qualify may be not less satisfied than adequately matched if, for example, they aim to mask or compensate their lack of skills or to access to employment. Whereas overqualification is habitually considered as suboptimal, consequence of a mismatch due to search or job frictions, the increasing dispersion in ability and/or skills among equally educated workers may induce individuals to voluntarily acquire more qualifications than those they can productively use in their jobs in order to compensate for a lack in those observed and unobserved skills or as a way of gaining access to employment or to search for a better job (McGuinness and Wooden, 2009; Verhaest and Omey, 2009; McGuinness and Sloane, 2011; Garcia-Mainar and Montuenga-Gomez, 2017). Even more, this signalling role of over-education may be especially important in periods of recession, and/or in areas where unemployment is high, since the decision to invest in education is not only regarded as a way to have access to higher wages but also as a way of insuring against unemployment. Thus, Clark and Oswald (2002) and Verhaest and 
Omey (2009) show that being unemployed produces a greater stigma than working at a job for which the individual is over-qualified.

We investigate the relationship between educational/skill mismatch and up to sixteen domains of job satisfaction for the Spanish case, a country with some specific features. First, in international perspective, the proportion of over-educated workers is among the highest within the OECD countries (OECD, 2011; Verhaest and van der Velden, 2013). Second, labour market is very slack; unemployment rate has consistently been among the highest within the EU during decades, and has risen to values over $25 \%$ during the Great Recession. Nowadays, it has reduced to values below 20\%, but still doubling the OECD average. Third, labour market is strongly segmented, with a temporary rate that has been the highest within the EU, around 30\%, during the last 30 years, generating a dual market and favouring the volatility of employment over time (Bentolila et al., 2012).

The data used in the paper, the Spanish Quality of Work Life Survey (Encuesta de Calidad de Vida en el Trabajo, ECVT henceforth), is of cross-sectional nature and prevents from longitudinal analysis. Hence, the use of Instrumental Variable (IV) estimation is needed in order to deal with endogeneity bias. In particular, the analysis of the association between each facet of job satisfaction and over-qualification is carried out through regression analysis taking into account both, the ordered nature of the dependent variable (each satisfaction domain) and the (plausible) appearance of endogeneity bias. Since satisfaction and over-qualification variables are both selfperceived by individuals, unobserved elements or reverse causation may be driving the final valuations of individuals. Results show that when endogeneity is not considered, over-qualification is systematically found to be negatively correlated with any domain of job satisfaction, corroborating the findings of previous literature. However, when dealing with endogeneity, in many dimensions of job satisfaction, the negative relationship is no longer observed.

The structure of the paper is as follows. Section 2 presents a summary of the literature and Section 3 describes the data, the diverse domains of job satisfaction and the concepts of mismatch used. In Section 4, we describe the methodology applied and present the estimated results. Finally, Section 5 concludes. 


\section{Literature review}

Several models have been proposed in the literature as possible explanations for the existence of over-education. The traditional economic argument based on the human capital theory is recurrently unsupported by empirical evidence, as is also the Thurow's (1975) job competition theory (see Dolton and Vignoles, 2000; Rubb, 2003; McGuinness, 2006; Brynin and Longhi, 2009; McGuinness and Wooden, 2009; Baert et al., 2013). Whereas the relationship between job satisfaction and over-qualification is habitually shown to be negative, empirical studies based on wage regressions typically find that over-educated workers earn more than adequately matched workers in the same kind of jobs, but less than adequately matched workers with the same amount of education. In other terms, over-educated workers face a wage penalty compared to equally educated individuals who are job-matched. These results give support to an assignment theory (Sattinger, 1993; Sloane, 2003; McGuinness, 2006), which rests on that not all similarly educated workers are equally productive in all jobs, but there exists heterogeneous skill/ability distribution, provoking mismatch in the allocation of workers to jobs (Chevalier, 2003; Green and McIntosh, 2007). Thus, some authors have found the absence of relationship between over-education and job satisfaction (e.g. Groot and Maassen van den Brink, 2000; Büchel, 2002) and even a positive relationship between over-education and firm's productivity (Kampelman and Ryck, 2012). Sloane (2003) argues that, unlike educational mismatches, skill mismatches have a strong negative impact on job satisfaction (see also, Allen and van der Velden, 2001; and Green and Zhu, 2010). This result is observed also for Spain in Badillo-Amador and Vila (2013). These results stress the need of studying the more general concept of overqualification instead of over-education.

Mismatch may be of transitory character if it disappears in a course of upwards career mobility (Sicherman and Galor, 1990; Sicherman, 1991; Alba-Ramírez, 1993) and then, over-qualified may not feel continuously less job-satisfied than adequatelymatched. However, most of recent studies tend to challenge the career mobility hypothesis (see Baert et al., 2013 and references therein) and find that over-qualification is a permanent phenomenon, making possible over-qualified being not as job-satisfied as adequately matched, establishing hence a negative relationship between overqualification and job satisfaction. Psychological literature usually finds that relative deprivation may explain why over-qualified workers feel dissatisfied and then perform worse than adequately matched and are more prone to leave the job (Bolino and 
Feldman, 2000; Feldman et al., 2002; Khan and Morrow, 1991; Maynard et al., 2006; Peiro et al., 2010).

Several studies find that apart from initial mismatch due to job search frictions, or inefficiency in the labour market, over-qualification may appear by other reasons such as to compensate for deficient human capital in other respects, for the lack of other skills, to reveal they are indeed qualified for a job, or to disguise among other more able individuals (Green et al., 2002; Ordine and Rose, 2009; Chevalier and Lindley, 2009). In slack labour markets, where unemployment is large, over-qualification may be used also by individuals to either gain access to the labour market, to improve their position in wage bargaining, or to show adaptability to a changing environment in the job market (Charlot et al., 2005; Fernández, 2006; Lene, 2011). Ortiz (2010) finds that overeducation is more common among permanent workers in Spain, since over-education allows workers not to achieve a better match, but a secure job. All these arguments suggest that over-qualification may be result from voluntary choices of individuals, and then not totally sub-optimal, thereby allowing for a non-negative relationship between over-qualification and job satisfaction.

Different studies, following the classification of Khan and Morro (1991), have differentiated between perceived mismatch (when education, experience or ability is higher than required in the job) and perceived no-grow (when the job hold by a workers lacks challenge), finding that the relationship with job satisfaction varies across dimensions. Johnson and Johnson (2000) further consider four facets of job satisfaction (overall, satisfaction with promotion, with supervisors and with pay). With surveyed data from 116 Postal Workers of a midwestern American Union local, they find at the cross sectional level that perceived no-grow is negatively related with work satisfaction and with satisfaction with supervision; and that perceived mismatch is negatively related with satisfaction with promotion and with satisfaction with pay. While it is found a negative relationship between the general domain of job satisfaction and overqualification, this relationship is influenced by different factors, such as challenge, status, autonomy, etc., among which some of them may have positive consequences for over-qualified workers. They conclude that "job setting is multidimensional and composed of different constituent parts with which an individual may be either satisfied or dissatisfied" (Johnson and Johnson, 2000: p.552). Johnson et al. (2002) obtain similar conclusions when adding some indicators on the willingness to remain or not in the organisation. 
Fine and Nevo (2008), and Erdogan and Bauer (2009), although obtain a negative relationship between perceived over-qualification and job satisfaction, provide convincing evidence of over-qualification to be positively related to job performance. Over-qualified are less satisfied than equally-qualified, adequately-matched, but they perform better than less-qualified, adequately-matched, showing that there are advantages to hiring employees who perceive that they are over-qualified.

Others authors have focused only on perceived mismatch since perceived no grow actually seems to allude to task characteristics (e.g., job interest, challenges), rather than to an education-related construct, and thus less adequate to capture over-qualification (Maynard et al., 2006; Peiro et al., 2010). Peiro et al. (2010) study the relationship between over-qualification and job satisfaction in Spain constructing three facets of job satisfaction: extrinsic, intrinsic and social significance. Extrinsic facets include salary, physical conditions, generous holidays, job security, promotion and working times. Intrinsic facets covers the facets about autonomy, skill utilization, task variety, learning opportunity, task significance, allow initiative and work with responsibilities. Finally, social significance includes contact with customer, contact with co-workers, social service, social status and supervisor guidance. All the individual facets are loaded into the three dimensions described through confirmatory factor analysis. They use a representative sample of 643 young Spanish employees (between 16 and 30 years old) living in the Valencian community and in the metropolitan cities of Barcelona and Madrid (Spain) to study the relationships between over-education and the three facets of job satisfaction as well as the direct and moderating role of salary, contract of employment, and work experience. After controlling for variables such as gender, age, education and region, they find a negative relationship between over-qualification and each of the three facets of job satisfaction whereas only work experience shows some moderating role. Maynard et al. (2006) examine the relationship between various types of underemployment and diverse job attitudes, including job satisfaction, surveying three distinct samples of US employees. They obtain that, although perceptions of underemployment are associated with poor job satisfaction, the relations are not equally strong for all underemployment dimension-attitude facet combinations; that is, relations between underemployment and satisfaction are domain-specific.

These results suggest, as a general conclusion, that over-qualified may feel no more dissatisfied than adequately educated, at least, no in all domains of job satisfaction, and the need of investigating the relationship while considering different facets of job satisfaction. A typical limitation of these studies is that the estimated relationship 
between over-qualification and facets of job satisfaction cannot be interpreted causally, since endogeneity may affect (Johnson and Johnson, 2000; Fine and Nevo, 2008; Peiro et al., 2010). We attempt to overcome this by using Instrumental Variable. Before doing that, we describe in Section 3 the data used.

\section{Data and descriptive results}

The data used in this paper come from the ECVT, a programme, started in 1999 and finished in 2010, produced by the Spanish Ministry of Employment that focuses on employment relationships and, more importantly for our research, on the valuations and attitudes of employees towards their work. The survey addresses employees older than 16 , living in households, as being representative of the total employed population, and covering a number of issues relating to working conditions, which allows us to control for a range of individual and job attributes. In particular, we focus on those that have to do with the qualification of individuals and their self-perceived job-match, as well as up to sixteen different domains of job satisfaction. Additional information is provided on socio-demographic variables of employees and on job conditions and attitudes of employees towards work. Overall, it combines objective information on labour, family, and individual characteristics, with pure subjective information on satisfaction with various facets of the job and with the job-match. Micro data are available from the Spanish Labour Ministry since 2001, with the exception of year 2005 when the survey was not carried out. The questionnaire differs throughout the period, with marked differences before and after year 2004. Our focus is then on the most recent period. Specifically, our sample is constructed from pooling the last four consecutive waves, from 2007 to 2010, producing an overall sample of 26,027 individuals.

We have computed over-qualification from a subjective point of view. In this general term we distinguish between over-education and skill under-utilisation. The overeducation literature typically considers three ways to measure it: subjective, objective and statistical. An objective measure is based on a comparison between the actual education level and the job-level requirements, established from an evaluation by professional job analysts. The statistical measure of over-education is obtained by comparing years of education attained by an individual with an indicator of the aggregate education level in the occupation in which that individual works. Finally, the subjective measure comes from worker self-assessments. It corresponds to the answer to the question whether the individual feels over- or under-educated for the work they do. 
Although subjective measures can be affected by classification errors, it is generally based on all the relevant information (Green and Zhu, 2010) and has more predictive power over the outcome than alternative measures (Johnson et al., 2002; Maynard et al., 2006), such that they are meaningful interpretations of the work environment (Johnson et al., 2002). Feldman et al. (2002) expresses this as subjective over-qualification being a more proximal predictor of employee attitudes and behaviours (see also, Liu and Wang, 2014).

Specifically, we first make use of the worker's responses to the following question.

QUESTION 1 Do you think that your current job is adequate according to your educational level?

With the possible answers being

1. Yes, correct. We label this as adequately educated

2. No, below. We label this as over-educated

3. No, above. We label this as under-educated

4. No, different. We label this as mismatched.

Since less than $3 \%$ of surveyed individuals choose answers 3 and 4, we discard these individuals in our analyses and consider only adequately matched and overeducated. ${ }^{1}$ According to Feldman's (1996) classification, this would correspond to the first dimension of underemployment: more education than required by the job. ${ }^{2}$ Table 1 shows the proportion of each of these groups in the total amount.

A second dimension of over-qualification and underemployment is skill underutilisation. This is more difficult to classify and measure. Here, it is approached by considering a second question in the ECVT:

\section{QUESTION 2 To what extent is your educational level useful for your job?}

Each individual rates between 0 , not at all, and 10, very much. The answer given to this question may be interpreted as an indicator of skills utilization, since it may well be the case that an individual declares herself as adequately matched and, simultaneously, reports a low degree of usefulness of her studies in her current job. We consider that the portion of the sample rating between 0 and 5 have acquired educational skills that are

\footnotetext{
${ }^{1}$ Apart from a possible reluctance of individuals to acknowledge being under-educated or mismatched, it is reasonable to consider that experience and on-the-job training may help workers to reduce the selfperception of being under-educated or mismatched.

${ }^{2}$ The classification includes five dimensions. The second is more experience or skills than required; the third refers to involuntary employment in a field outside of area of education; the fourth, to involuntary employment in part-time, temporary or intermittent work; and the fifth, to underpayment. The two latter are not directly related to qualification and are not studied here.
} 
hardly applicable to their jobs (non-useful skills), whereas the half rating 6 or above are thought to make great use of their acquired educational skills (useful skills). ${ }^{3}$

Taking responses to both questions, we can construct a classification of employees according to a self-evaluated mismatch (see Table 1). We define as "properly matched" those who answer 1 to the first question and simultaneously rate 6 or more to the second question. They are neither over-educated nor over-skilled and represent almost two thirds of the whole sample. Those who answer 2 to the first question are labelled as over-educated. We can distinguish between "apparent", those who report 6 or above to the second questions (over-educated but not over-skilled), and "genuine", those who report 5 or below (over-educated and over-skilled). The remaining individuals, about $15 \%$ of observations, correspond to individuals who report there is not much of a relationship between their realized studies and the tasks they perform at work. These are more difficult to classify; they are differently qualified and we designate them as "unadjusted". These can approximate a third dimension of underemployment, those who are employed in a field outside of area of education (Feldman, 1996). Whereas responses to QUESTION 1 allow distinguishing between adequately-educated and overeducated, the combination of responses to both questions permits to partially capture skill heterogeneity among individuals, and distinguish between properly-matched; unadjusted; apparent over-qualified; and genuine over-qualified. Both classifications will be considered in our subsequent analyses.

\section{(Table 1 about here)}

Workers are asked a number of questions concerning different aspects of job satisfaction. The overall assessment on job satisfaction at the current job is derived from the answer to the question "indicate the satisfaction degree in their current (main) job", which is rated - on an eleven-point scale - from 0 (no satisfaction) to 10 (very high satisfaction). Average general job-satisfaction for the pooled 2007-2010 period is rated at 7.29. Only a lower than $20 \%$ proportion of respondents admits to a job satisfaction rate below 6. While in many cases (see Johnson et al., 2002; Peiro et al., 2010, among others) the chosen facets of job satisfaction are constructed through confirmatory factor analysis from the answers of individuals in short samples to different items, we use the nationally representative ECVT which directly offers the rates for each of the

\footnotetext{
${ }^{3}$ Other possibilities have been also considered in estimations. Although the percentage of individuals in each group varies, estimated results do not significantly change with respect to those presented in the next sections.
} 
satisfaction dimensions under considerations. The advantages of using large nationally representative samples have been asserted elsewhere (f.i., Liu and Wang, 2012).

Table 2 shows the definition of the different domains considered of satisfaction at the workplace, their corresponding overall average values, as well as distinguishing between over-educated and adequately educated (according to QUESTION 1), and across the four groups aforementioned (combining answers to QUESTIONS 1 and 2). It can be seen that the general valuation of satisfaction is generally larger than those of the particular domains considered. Whereas many domains show an average value between 6.5 and 7.7, lower values (less than 5) are observed for satisfaction with promotion prospects and with training. Pay satisfaction is near 6 and the lowest value, 3.3, is attached to satisfaction with social benefits or aids provided by the firm. We compute partial correlations between each domain of satisfaction and the general assessment of the job satisfaction finding that they are all positively correlated, but are far from perfect. Thus, the highest coefficients (around 0.60) correspond to satisfaction with activity in work and satisfaction with personal development, and the lowest (between 0.28 and 0.36 ) satisfaction with hour flexibility and satisfaction with firm-provided social benefits. ${ }^{4}$

On its part, over-educated systematically report lower rates of satisfaction for all domains than those who are adequately educated. ${ }^{5}$ Many differences are about one-scale point, with the two largest exceeding 1.4 (satisfaction with personal development and with training) and the lowest being smaller than 0.5 (satisfaction with working day and vacations). When considering the differences in the set of satisfaction domains between the four types defined of match, in general, properly matched are more satisfied than unadjusted; these more than apparently over-qualified; and these latter more than genuinely over-qualified (values ranging from properly to genuine over-qualified between 1 and 2 -scale points). In some cases rates for apparently over-qualified are not lower than those of unadjusted.

\section{Methodology and results}

\subsection{Ordered probit estimation}

We follow the standard approach, regressing each domain of satisfaction, and overall job satisfaction, on a range of personal and job characteristics at the individual level,

\footnotetext{
${ }^{4}$ Results not shown but available from the authors upon request.

${ }^{5}$ Median values (not shown) provide an identical conclusion. 
adding self-perceived variables capturing over-qualification, according to the following expression:

$$
D S_{i t}^{j}=\alpha+\lambda_{t}+\beta_{0} X_{i t}+\gamma_{0} M_{i t}+\varepsilon_{i t}
$$

where self-reported satisfaction, DS for each domain $j$, of individual $i$, in year $t$ depends on the year dummies $\left(\lambda_{t}\right)$, a vector of individual socio-demographic and job characteristics $\left(\mathrm{X}_{\mathrm{it}}\right)$ and dummies capturing over-qualification $\left(\mathrm{M}_{\mathrm{it}}\right)$.

An important matter referring to our dependent variable is whether the different domains of satisfaction are assumed to be ordinal-interpersonal comparable, or cardinalinterpersonal comparable (Ferrer-i-Carbonell and Frijters, 2004). Interpersonal comparability means that when two respondents give the same answer, they are assumed to enjoy similar satisfaction levels. That is, "individuals have a common understanding of how to translate internal feelings into a number scale, so that numerical values from different individuals are roughly the same" (Ferrer-i-Carbonell and Frijters, 2004: 644). Assuming cardinality supposes that the differences between satisfaction rates are not dependent on the rate itself (i. e. the difference between rating 7 and rating 6 is the same as the difference between scores 3 and 2). In consequence, an individual rating 8 , for example, is twice as satisfied as an individual rating 4 . In this context, empirical analysis can be done with OLS. However, when ordinality is assumed differences between the rates are not considered to be independent on the rate itself. In this case, an individual rating 8 is more satisfied than another individual rating 4 , but the difference is not informative on the relative valuation. The empirical analysis requires hence the use of latent variable models, ordered probit or ordered logit. The assumption of ordinal-interpersonal comparability is then less restrictive and results for ordered probit are now examined in detail. ${ }^{6}$

At the moment we present ordered probit estimates of equation (1) without considering the bias associated with potential endogeneity, to be discussed below. Thus, causality is not investigated and coefficients should be interpreted as only partial correlations. Table 3 shows the results of estimating the relationship between selfperceived over-qualification and the overall concept of job satisfaction while controlling for a set of (observable) personal and job characteristics. Controls that moderate the negative relationship between over-qualification and (domains of) job satisfaction

\footnotetext{
${ }^{6}$ We also estimated by OLS. Ferrer-i-Carbonell and Frijters (2004) find that the assumption of cardinality or ordinality does not qualitatively change the results in the studies of happiness, and many non-economic papers rely on OLS estimates since their interpretation is more straightforward. We find little qualitative difference between the results of those approaches. OLS estimates are not reported but are available upon request.
} 
include, in addition to years, gender, educational attainment, occupational category, age (in quadratic terms), nationality, city-population size, working hours, income ranges, type of contract, training at work, activity branches, tenure (in quadratic terms), being in a first job, firm size, unionisation and family variables (marital status, number of child in different age ranges).

The inclusion of earnings is essential. With no market failures, preferences over job amenities would be internalised in the labour market through wages (compensating wage differentials) and one would then not find any separate effect of, say, worked hours or type of contract on any domain of job satisfaction after controlling for income or wages. Nevertheless, studies systematically do find statistical and quantitatively significant effects of various job amenities on job satisfaction as, for example, type of contract (Booth et al., 2012), over-education (Cabral-Viera, 2005), job stability (Origo and Pagani, 2009) or empowerment (Erdogan and Bauer, 2009); thereby contending the competitive view. In other words, any job characteristics that influence utility/job satisfaction may offset, or reinforce, the effect of over-qualification. In consequence, it is necessary to condition the analysis on the characteristics of the job.

Our own results confirm this. The estimates for variables included in our analysis typically follow the standard behaviour in the literature (see Dolan et al., 2008; GarcíaMainar et al., 2016, for the case of Spain). Age and tenure variables have the typical U shape, indicating that, in the early years, satisfaction declines and then increases. Foreign workers are more satisfied, ceteris paribus, than native Spanish workers. Men are less satisfied than women. Higher education and larger population-size cities are associated with lower job satisfaction. The family structure is found to be an important element in shaping job satisfaction: marriage is associated with higher job satisfaction, whereas having infants at home is linked to lower job satisfaction. Regarding workrelated variables, working longer hours results in lower satisfaction. Higher income is positively associated with greater job satisfaction. Labour stability and training at work both lead to increases in job satisfaction, with workers being generally more satisfied in non-manual occupations and in services. Being in a first job is positively related to job satisfaction, while firm size and unionisation both reduce job satisfaction.

\section{(Table 3 about here)}

Table 4 shows the estimated coefficients of the over-qualification variables for each domain of job satisfaction. The rest of the coefficients are not reported to save space. They show a similar pattern to that described for overall job satisfaction, and results are available from the authors upon request. 


\section{INSERT TABLE 4}

Focusing on our variables of interest, we consider alternatively the specification distinguishing between over-educated and adequately matched (first column, Table 3 and 4), and the one that simultaneously consider properly matched, unadjusted, apparently over-qualified and genuinely over-qualified (second block of columns, Table 3 and 4). In both specifications results are coincident: over-qualification conveys losses in satisfaction for employees with respect to those who are adequately-educated and properly-matched, respectively. First column in Table 4 shows that over-educated are less satisfied than adequately-educated for every domain of job satisfaction, even after controlling for an ample set of personal, family and job-related variables. When studying different degrees of over-qualification, it can be seen in the next block of columns, that the negative relationship is the strongest in the case of genuinely overeducated followed by apparently over-educated and finally by those unadjusted, concluding thereby that the highest the mismatch, the least satisfied an individual is for any domain of job satisfaction.

On concluding, being in a job requiring less qualification that those held by the employee supposes less satisfaction in all the facets or domains of job satisfaction we have studied. The fact that mismatch is sub-optimal and hence a situation not pursued by employees is immediately derived. Results fit well the relative deprivation theory.

\subsection{Addressing endogeneity through IV estimation}

When estimating equation (1) we face certain difficulties. The fact that perceived overqualification and satisfaction, in different domains, are both evaluated subjectively, makes endogeneity biases likely to arise. Whereas results in Table 4 show that there exists a strong negatively relationship between self-perceived over-qualification and measures of satisfaction in different domains, these results may be driven by individual psychological characteristics or personal traits that simultaneously influence in perceived educational mismatch and job satisfaction. Thus, unobserved characteristics that are omitted from the equation, such as self-esteem, anger or boredom, are likely to affect both self-perceived levels of job-match and satisfaction in the workplace. In addition to this problem of common unobserved determinants, reverse causation may be also at work. Individuals who feel more mismatched may become more dissatisfied in the workplace, and then, report lower levels of job satisfaction in different facets; but, also, individual with low levels of satisfaction in certain spheres of the job may report to be more discontented with their qualification/job match. Both possibilities suggest an 
endogeneity problem, leading to biased and inconsistent estimates of the causal effect of self-perceived mismatch on the subjective evaluation of facets of job satisfaction.

Since our data are repeated cross-sections, we cannot control for unobserved individual heterogeneity through panel data estimation. One standard approach to account for it is to use IV estimation. This attempts to instrument subjective educational mismatch in order to obtain consistent estimates through 2SLS or GMM. However, the treatment of endogeneity when the dependent variable is ordered is not straightforward. In this context, the two-step method (2SLS) can be viewed only as an approximation of the correct estimator (see e.g. Van de Ven and Van Praag, 1981; Bryson et al., 2004; García-Mainar et al., 2016). A simple way to circumvent this is by assuming that the dependent variable is cardinal. As mentioned above, assuming either ordinality or cardinality of happiness scores has little effect on the qualitative empirical results (Ferrer-i-Carbonell and Frijters, 2004).

We then assume that job satisfaction is cardinal, so that IV estimation can be carried out to control for endogeneity, and tests for exogeneity of the regressors and for the validity of instruments can be routinely used. To aid identification of the effects of interest, we formulate a set of exclusion restrictions. We need to make assumptions about the variables that affect over-qualification but, conditional on these, have no residual impact on each domain of job satisfaction. Specifically, we construct an objective measure of over-qualification through a dummy variable which takes value 1 if the employee has university studies but work in a manual or services unskilled occupations, and 0 otherwise. ${ }^{7}$ Since this measure of over-education is objective, endogeneity biases in the estimation of the relationship between over-qualification and each domain of job satisfaction are (at least) partially controlled for. An equation (2) is added

$$
M_{i t}=\alpha+\lambda_{t}+\delta_{0} Z_{i t}+\delta_{1} O Q_{i t}+v_{i t}
$$

where $Z_{i t}$ is a vector of explanatory exogenous variables included in equation (1) and $O Q_{i t}$ is the instrument (either the dummy variable capturing over-education or the ordered variable according to definition 2, whose values are, respectively, 0 properly matched, 1 unadjusted, 2 apparently over-qualified and 3 genuinely over-qualified.) The fitted values for $\mathrm{M}$ obtained in this equation are introduced in the estimation of equation

\footnotetext{
${ }^{7}$ Manual and services occupations correspond to groups 4, 5, 8 and 9 of the one-digit 1994 CNO Clasificación Nacional de Ocupaciones (National Classification of Occupations). This is based on the 1988 ISCO classification, but they do not entirely coincide. Group 4: Clerks; group 5: Services and sales workers; group 8: Machine operators and assemblers; group 9: Elementary occupations.
} 
(1), with estimated values shown in the last columns: estimates for the whole set of coefficients in the case of overall job satisfaction in Table 3 (they show a similar pattern to that in the ordered probit case) and for the coefficients of interest for each domain of job satisfaction in Table 4.

Table 5 reports the results of the tests for exogeneity of the over-qualification variable. When distinguishing between the adequately-educated and the over-educated, the standard Wu-Hausman test rejects the exogeneity of over-qualification in most of the cases (only in overall job-satisfaction, satisfaction with activity, satisfaction with hour flexibility, satisfaction with job stability and satisfaction with training exogeneity is non-rejected), such that inference should be made on coefficients estimated by IV. ${ }^{8}$ The estimated coefficients for over-education, once endogeneity is controlled for (in those cases where it is found that this variable is considered as endogenous), make a marked difference with those shown in first column of Table 4. Now, there are many facets of job satisfaction for which over-educated are not less satisfied than adequatelyeducated. Only in the dimensions of activity, personal self-fulfilment, autonomy and participation, as well as in the overall dimension, those who are over-educated are significantly less satisfied than adequately matched. In the rest of cases, the relationship is either negative (satisfaction with firm's organisation) ${ }^{9}$ or positive (satisfaction with promotion, satisfaction with relations with management, with workday, with duration of breaks, with paid vacations, with pay, with social support and with health and safety at work), but no longer statistically significant. These results point out at that reverse causation or individual heterogeneity problems may be biasing the estimates, and more dissatisfied workers likely reporting to be inadequately matched.

When the over-qualification instrument/variable is captured by the ordered variable indicating the degree of mismatch, this variable is found to be exogenous -in statistical terms- only in the cases of satisfaction with activity and satisfaction with hour flexibility. ${ }^{10}$ This leads to focus on the ordered probit estimates on these two domains only, finding that the relationship between over-qualification and these two domains of job satisfaction is negative. The fact that only in two cases over-qualification can be considered as exogenous, may be suggesting that as the indicator of over-qualification is

\footnotetext{
${ }^{8}$ The elaborated objective measure of over-education, that acts as the instrument, is found to be not weak (F-statistics are much above the critical value).

9 The other domains in which the relationship is estimated to be negative, satisfaction with hour flexibility, with job stability and with training, the relevant sign is obtained from ordered probit estimation (first column of Table 4) since, in these cases, over-education is found to be exogenous.

${ }^{10}$ The same elaborated objective measure of over-education is used as instrument, and again is found to be not weak in all the cases (see the F-statistics under the IVreg heading).
} 
more precisely measure, the same elements influencing in self-perceived overqualification, affect the reported value of satisfaction (except in the two cases aforementioned). Dealing with endogeneity using OQ as instrument, we find similar result to those obtained in the case where we distinguish only between adequatelymatched and over-educated. The relationship is also negative and statistically significant, in addition to satisfaction with activity and satisfaction with hour flexibility, in the overall domain of job satisfaction and in the facets of personal self-fulfilment, autonomy, participation, and marginally, in satisfaction with training. In the rest of the cases, the relationship is not statistically significant, either positive or negative.

On conclusion, controlling for endogeneity reveals that in many facets over-qualified are similarly satisfied to the adequately-matched suggesting that over-qualification does not necessarily lead to lower levels of satisfaction or sense of deprivation. Whereas in the overall domain of job satisfaction over-qualified are indeed less satisfied, as usually found in the literature, this negative relationship is observed in some few facets such as satisfaction with the activity developed in work, with self-fulfilment, with autonomy at work and with the participation in the decisions related to job tasks. Only in these cases, over-qualified do really feel deprived with respect to workers adequately-matched. In the other domains of job satisfaction under consideration, an over-qualified worker does not feel worse than a properly-matched. Thus, in facets such as relations with management, paid vacations, duration of breaks, workday, job stability or earnings, there are hardly differences in satisfaction between over-qualified and adequatelymatched.

If job satisfaction can be considered as a predictor of job performance or voluntary turnover, it seems that the general concept it is in fact negatively related with overqualification and then individuals may feel deprived. However, in many other facets this is not true and over-qualified workers are as satisfied as perfectly matched workers. Thus, it is not unexpected that, at least some individuals, may get over-qualified not only as a consequence of mismatch due to frictions in job search, job mobility or in other labour market imbalances, but also as a way to obtain some reward compensating disadvantages from over-qualification. Specifically, the evidence obtained in our study indicates that they do not feel less satisfied in earnings, health conditions and safety at work, promotion prospects or job stability, among several others.

\section{Discussion and conclusions}


There exists large empirical evidence showing a negative influence of over-qualification on satisfaction which can be rationalised into relative deprivation arguments. However, job satisfaction can be seen as an array of different domains/facets of satisfaction related to performance in the job place. In fact, different studies find that over-qualified workers feel less satisfied in some domains and more satisfied in other domains than adequately matched. For example, if workers over-qualify to obtain a more permanent position or just to escape from unemployment, then they may report a valuation of satisfaction with job stability or job promotion not very different from that reported by an adequately matched worker, counterbalancing lower valuations corresponding to other domains, such as pay or self-fulfilment.

In this paper, we deepen into this argument by hypothesising that, individuals who over-qualify may be not less satisfied than adequately matched if they aim to mask or compensate their lack of skills or to access to employment. Whereas over-qualification is habitually considered as suboptimal, consequence of a mismatch due to search or job frictions, the increasing dispersion in ability and/or skills among equally educated workers may induce individuals to voluntarily acquire more qualifications than those they can productively use in their jobs in order to compensate for a lack in those observed and unobserved skills or as a way of gaining access to employment or to search for a better job. Even more, this signalling role of over-education may be especially important in periods of recession, and/or in areas where unemployment is high, since the decision to invest in education is not only regarded as a way to have access to higher wages but also as a way of insuring against unemployment.

Our results suggest that the relationships between over-qualification and job satisfaction are better measured when considering different domains or facets of the job satisfaction concept. When taking into account simultaneity or reverse causation, the negative relationship seems to remain in the general notion of job satisfaction, as well as in intrinsic facets of job satisfaction such as activity developed, self-fulfilment, autonomy and participation in decisions. The relationship is not negative, overqualified do not feel relatively deprivated with respect to adequately matched in extrinsic facets (paid vacations, breaks' duration, workday, job security/stability and earnings) or social relations (relations with management). These results are different to those from Peiro et al. (2010) since they find that three facets (extrinsic, intrinsic and social) are negatively related with over-qualification. Two circumstances may explain these different findings. First, whereas we make use of a national representative sample of Spanish workers evaluation sixteen different domains of job satisfaction, Peiro et al. (2010) use a sample 
of individual from three regions of Spain and construct the aggregate facets of job satisfaction from several questions in the survey through confirmatory analysis. Second, and more important, as Peiro et al (2010) acknowledges, the relationship they found cannot be interpreted causally, calling for the need of propensity score or IV techniques. This is what we have done here, so that reverse causation and/or simultaneity bias are dealt with. In fact, our results mimics theirs in that a negative relationship is observed between over-qualification and any domain of job satisfaction when endogeneity is ignored.

In short, whereas over-qualified are less satisfied in the overall dimension of job satisfaction, this is not completely true when considering different domains suggesting that a robust assessment of determinants of job satisfaction implies analysing different facets in the job place. This provides some support to the idea that some degree of overqualification is voluntarily chosen. It remains to explain which is the mechanism driving this behaviour. The cross-sectional nature of data limits the analysis and forces us to left this for future research. 


\section{References}

Alba-Ramirez, A. (1993). Mismatch in the Spanish Labor Market: Over-education? Journal of Human Resources, 28, 259-278.

Allen, J. and R. Van der Velden 2001. Educational Mismatches versus Skill Mismatches: Effects on Wages, Job Satisfaction, and On-the-job Search. Oxford Economic Papers, 533, 434-452.

Badillo-Amador, L. L. and Vila (2013): "Education and skill mismatches: wage and job satisfaction consequences", International Journal of Manpower, vol. 34, pp. 416-428.

Baert, S., B. Cockx and D. Verhaest (2013). Over-education at the Start of the Career: Stepping Stone or Trap. Labor Economics, 25, 123-140.

Bedard K. (2001). Human Capital versus Signaling Models: University Access and High School Dropouts. Journal of Political Economy, 109, 749-775.

Bentolila, S., Cahuc, P., Dolado, JJ. and T. Le Barbanchon (2012). Two-tier Labor Markets in the Great Recession: France versus Spain. Economic Journal 122, 155187.

Bills, D. (1992). The Mutability of Educational Credentials as Hiring Criteria: How Employers Evaluate Atypically Highly Credentialed Job Candidates. Work and Occupations 19 (1), 79-95.

Bolino, M.C., \& Feldman, D.C. (2000). The Antecedents and Consequences of Underemployment among Expatriates. Journal of Organizational Behavior, 21, 8, 889-911.

Booth, A., M. Francesconi and J. Frank, J. (2002): “Temporary jobs: stepping stones or dead ends?", The Economic Journal, vol. 112, pp. F189-F213.

Brynin, M., Longhi, S. (2009). Overqualification: Major or Minor Mismatch? Economics of Education Review, 28, 114-121.

Bryson, A., L. Cappellari and C. Lucifora (2004): "Does union membership really reduce job satisfaction?, British Journal of Industrial Relations, vol. 42, pp. 439-459.

Büchel, F. 2002. The Effects of Over-education on Productivity in Germany. The Firm's Viewpoint. Economics of Education Review, 213, 263-276.

Cabral Vieira, J. (2005): "Skill mismatches and job satisfaction", Economic Letters, vol. 89 , pp. 39-47.

Chevalier, A. 2003. Measuring Over-education. Economica, 70279, 509-531.

Chevalier, A. and Lindley, J. 2009. Over-education and the skills of UK graduates. Journal of the Royal Statistical Society: Series A, 172:307-337. 
Clark and Oswald (2002). A simple statistical method for measuring how life events affect happiness. International Journal of Epidemiology, 31 (6), 1139-44.

Crosby, F. (1976). A model of egoistical relative deprivation. Psychological Review, $83,85-113$.

Crosby, F. (1984). Relative deprivation in organizational settings. In B. M. Staw \& L. L. Cummings (Eds.), Research in organizational behaviour (Vol. 6, pp. 51-93). Greenwich, CT: JAI Press.

Dolan, P., Peasgooda, T. and Whiteb, M. (2008): Do we really know what makes us happy? A review of the economic literature on the factors associated with subjective well-being, Journal of Economic Psychology, 29(1), 94-122.

Dolton, P. and Vignoles, A. (2000). The Incidence and Effects of Over-education in the U.K. Graduate Labor Market. Economics of Education Review, 19, 179-198.

Erdogan, B., \& Bauer, T.N. (2009). Perceived overqualification and its outcomes: The moderating role of empowerment. Journal of Applied Psychology, 94(2), 557-565.

Erdogan, B., Bauer, T.N., Peiró, J.M., \& Truxillo, D.M. (2011). Overqualified employees: Making the best of a potentially bad situation for individuals and organizations. Industrial and Organizational Psychology, 4, 215-232.

Feldman, DC. (1996). The nature, antecedents, and consequences of underemployment. Journal of Management, 22, 385-407.

Feldman, D. C., Leana, C. R., \& Bolino, M. C. (2002). Underemployment and relative deprivation among re-employed executives. Journal of Occupational and Organizational Psychology, 75, 453-471.

Fernández, C. 2006. The Role of Education Vis-à-vis Job Experience in Explaining the Transitions to Employment in the Spanish Youth Labor Market. Spanish Economic Review, 8, 161-187.

Ferrer-i-Carbonell, A., Frijters, P. 2004. How Important is Methodology for the Estimates of the Determinants of Happiness? The Economic Journal 114, 641-659.

Fine, S., \& Nevo, B. (2008). Too smart for their own good? A study of perceived cognitive overqualification in the workforce. The International Journal of Human Resource Management, 19, 346-355.

García-Mainar, I., G. García-Martín and V. Montuenga (2016): Gender differences in occupations, job attributes, and job satisfaction. Revista de Economía Aplicada, 71(XXIV), 39-67.

Garcia-Mainar, I. and VM. Montuenga 2017. Subjective educational mismatch and signalling in Spain. DT Econz 2017-03. University of Zaragoza, Spain. 
Green, F. and McIntosh, S. 2007. Is there a genuine under-utilization of skills among the over-qualified? Applied Economics, 39:427-439.

Green, F., McIntosh, S., Vignoles, A., 2002. The utilization of education and skills: evidence from Great Britain. The Manchester School 70, 792-811.

Green, F. and Zhu, Y. 2010. Overqualification, job dissatisfaction, and increasing dispersion in the returns to graduate education. Oxford Economic Papers, 624, 749763.

Groot, W. and Maassen van den Brink, H. 2000. Over-education in the labor market: A meta-analysis. Economics of Education Review, 192:149-158.

Hartog, J. 2000. Over-education and earnings: where are we, where should we go? Economics of Education Review, 192:131-147.

Holton, B. Lee, T., Tidd, S. (2002) The Relationship between Work Status Congruence and Work-Related Attitudes and Behaviors. Journal of Applied Psychology 87(5):903-15.

Johnson, G. J., \& Johnson, W. R. (2000). Perceived overqualification and dimensions of job satisfaction: A longitudinal analysis. Journal of Psychology, 134, 537-555.

Johnson, W.R., Morrow, P.C., \& Johnson, G.J. (2002). An evaluation of a perceived overqualification scale across work settings. Journal of Psychology, 136, 425-441.

Kampelmann, S. and F. Rycx 2012. The Impact of Educational Mismatch on Firm Productivity: Evidence from Linked Panel Data. Economics of Education Review, 31, 918-931.

Khan, L.J., \& Morrow, P.C. (1991). Objective and Subjective Underemployment Relationships to Job Satisfaction. Journal of Business Research, 22, 211- 218.

Lee, HM., Chou, MJ, Wu, HT (2016). The measurement of perceived overqualification and the relationships among perceived overqualification, psychological empowerment, job satisfaction of private kindergarten teachers. European Journal of Research in Social Sciences, 4 (8), 1-15.

Lene, A. 2011. Occupational downgrading and bumping down: The combined effects of education and experience, Labour Economics 18, 257-269.

Leuven, E. and Oosterbeek, H. 2011. Over-education and Mismatch in the Labor Market. In Eric A. Hanushek, Stephen Machin and Ludger Woessmann eds.: Handbook of the Economics of Education. Volume 4: 283-326.

Liu, S., \& Wang, M. (2012). Perceived overqualification: A review and recommendation for research and practice. Research in Occupational Stress and WellBeing, 10, 1-42. 
Maynard, D.C., and Hakel, M.D. (1999), "Managerial Perceptions of Over-qualification in the Selection Process", paper presented at the 14th Annual Conference of the Society for Industrial and Organizational Psychology (SIOP), Atlanta, GA.

Maynard, D. C., Joseph, T. A., \& Maynard, A. M. (2006). Underemployment, job attitudes, and turnover intentions. Journal of Organizational Behavior, 27, 509-536.

McGuinness, S. 2006. Over-education in the labor market. Journal of Economic Surveys, 203:387-418.

McGuinness, S., Sloane, P., 2011. Labour market mismatch among UK graduates: An analysis using REFLEX data. Economics of Education Review, 30, 130-145.

McGuinness, S., Wooden, M. 2009. Overskilling, job insecurity, and career mobility. Industrial Relations, 48, 265-286.

OECD 2011 Right for the Job: Over-Qualified or Under-Skilled, OECD Employment Outlook 2011, OECD Publishing, Paris, 191-235.

Ordine, P., Rose. G 2009. Over-education and Instructional Quality: A Theoretical Model and Some Facts. Journal of Human Capital, 2009, vol. 31, 73-105

Origo F. and L. Pagani (2009): "Flexicurity and job satisfaction in Europe: the importance of perceived and actual job stability for well-being at work", Labour Economics, vol. 16, pp. 547-555.

Ortiz, L. 2010. Not the Right Job, but a Secure One: Over-education and Temporary Employment in France, Italy and Spain. Work, Employment and Society, 241, 47-64.

Peiro, JM., Agut, S and Grau, R. (2010). The Relationship Between Overeducation and Job Satisfaction Among Young Spanish Workers: The Role of Salary, Contract of Employment, and Work Experience, Journal of Applied Social Psychology,40, 3, pp. 666-689.

Rubb, S. (2003b) Over-education in the labor market: a comment and re-analysis of a meta-analysis, Economics of Education Review, 22, 621-9.

Sattinger, M. (1993) Assignment Models of the Distribution of Earnings. Journal of Economic Literature, 31(2), 831-880.

Sicherman, N. (1991). Over-education in the labor market. Journal of Labor Economics, 9(2):101.

Sicherman, N. and Galor, O. (1990). A theory of career mobility. Journal of Political Economy, 98(1):169-192.

Sloane, P. 2003. Much ado About Nothing? What does the Over-education Literature Really Tell us. In Büchel, F., De Grip, A., and Mertens, A., editors, Over-education in Europe; Current issues in theory and policy, pages 11-45. Edward Elgar. 
Taber, T. and Alliger, G. (1995). A task-level assessment of job satisfaction. Journal of organizational behaviour 16, 101-121.

Thurow, L. (1975) Generating inequality. Basic Books.

Tsang, M., Rumberger, R., Levin, H., 1991. The impact of surplus schooling on worker productivity. Industrial Relations 30, 209-228.

Van de Ven, W. P. and B.M.S. Van Praag (1981): "The demand for deductibles and private health insurance: a probit model with sample selection”, Journal of Econometrics, vol. 17, pp. 229-52.

Verhaest, D. and Omey, E. (2006). The Impact of Over-education and its Measurement. Social Indicators Research, 77, 419-448.

Verhaest, D. and Omey, E. 2009. Objective Over-education and Worker Well-being: A Shadow Price Approach. Journal of Economic Psychology, 30, 469-481.

Verhaest, D. and R. van der Velden 2013. Cross-country Differences in Graduate Overeducation. European Sociological Review, 293, 642-653. 
Table 1 Definitions and percentages of over-qualification

Question 2 Non-useful skills (0-5 rate)

\section{Question 1}

$$
26.7 \%
$$

Adequately educated (80.7\%)

Unadjusted (18.0\%)

Over-educated (19.3\%)

Genuinely over-educated (8.7\%)

Useful skills (6-10 rate)

$$
73.3 \%
$$

Source: Own elaboration from ECVT 2007-2010.

Properly matched (62.7\%)

Apparently over-educated (10.6\%)

\begin{tabular}{|c|c|c|c|c|c|c|c|c|}
\hline $\begin{array}{l}\text { Please, rate your satisfaction with the following aspects } \\
\text { in your job place. How satisfied are you with the } \\
\text { following job aspects? }\end{array}$ & Mean & $\begin{array}{l}\text { Adequately- } \\
\text { educated }\end{array}$ & $\begin{array}{l}\text { Over- } \\
\text { educated }\end{array}$ & Adjusted & Unadjusted & $\begin{array}{c}\text { Apparently } \\
\text { over-qualified }\end{array}$ & $\begin{array}{l}\text { Genuine } \\
\text { over-qualfied }\end{array}$ & $\begin{array}{c}\text { Number } \\
\text { observations }\end{array}$ \\
\hline Job satisfaction & 7.29 & 7.47 & 6.47 & 7.62 & 7.06 & 6.82 & 6.05 & 26,027 \\
\hline Firm's work organisation & 6.89 & 7.05 & 6.17 & 7.17 & 6.80 & 6.38 & 5.92 & 26,027 \\
\hline Promotion prospect & 4.99 & 5.20 & 4.09 & 5.49 & 4.20 & 4.60 & 3.47 & 23,884 \\
\hline Recognition of the work / relations with management & 7.09 & 7.26 & 6.35 & 7.38 & 6.93 & 6.62 & 6.02 & 25,056 \\
\hline Activity in work & 7.68 & 7.87 & 6.88 & 8.00 & 7.49 & 7.26 & 6.40 & 26,027 \\
\hline Personal development / Self-fulfilment & 7.42 & 7.67 & 6.31 & 7.81 & 7.25 & 6.81 & 5.70 & 26,027 \\
\hline Level of freedom/ autonomy at work & 7.27 & 7.43 & 6.60 & 7.57 & 6.99 & 6.94 & 6.18 & 26,027 \\
\hline Participation in decisions related to job tasks & 6.57 & 6.78 & 5.62 & 7.02 & 6.05 & 6.16 & 4.95 & 25,389 \\
\hline Workday /Working day & 7.16 & 7.26 & 6.68 & 7.37 & 6.97 & 6.93 & 6.38 & 26,027 \\
\hline Hour flexibility & 6.27 & 6.41 & 5.65 & 6.58 & 5.89 & 6.04 & 5.17 & 26,027 \\
\hline Duration of work breaks & 6.63 & 6.76 & 6.07 & 6.89 & 6.37 & 6.37 & 5.70 & 26,027 \\
\hline Paid vacations & 7.41 & 7.53 & 6.87 & 7.71 & 6.97 & 7.23 & 6.43 & 26,027 \\
\hline Job stability & 7.38 & 7.54 & 6.69 & 7.74 & 6.93 & 7.15 & 6.12 & 26,027 \\
\hline Firm's provided training & 5.73 & 6.00 & 4.53 & 6.37 & 4.80 & 5.22 & 3.67 & 25,151 \\
\hline Earnings/ pay/ salary & 6.01 & 6.20 & 5.16 & 6.39 & 5.61 & 5.46 & 4.79 & 25,948 \\
\hline Firm's provided social support & 3.29 & 3.43 & 2.67 & 3.71 & 2.47 & 3.13 & 2.09 & 23991 \\
\hline Health and safety at work & 7.31 & 7.43 & 6.79 & 7.53 & 7.13 & 7.04 & 6.49 & 26027 \\
\hline
\end{tabular}

Table 2 Average job satisfaction across groups 
Table 3 Estimates of job satisfaction regression

\begin{tabular}{|c|c|c|c|c|c|c|c|c|}
\hline \multirow[b]{2}{*}{ Job satisfaction } & \multicolumn{4}{|c|}{ Ordered probit } & \multicolumn{4}{|c|}{ ivregress } \\
\hline & Coef. & Std.Err. & Coef. & Std.Err. & Coef. & Std.Err. & Coef. & Std.Err. \\
\hline Over-education & $-0.548 * * *$ & 0.018 & & & $-0.639 * * *$ & 0.236 & & \\
\hline Unadjusted & & & $-0.224 * * *$ & 0.018 & & & $-0.238 * * *$ & 0.086 \\
\hline Apparently & & & $-0.451 * * *$ & 0.022 & & & & \\
\hline Genuine & & & $-0.781 * * *$ & 0.025 & & & & \\
\hline Male & $-0.071 * * *$ & 0.015 & $-0.071 * * *$ & 0.015 & $-0.107 * * *$ & 0.025 & $-0.097 * * *$ & 0.025 \\
\hline Education2 & 0.166 & 0.182 & 0.285 & 0.182 & 0.265 & 0.295 & $0.643 * *$ & 0.317 \\
\hline Education3 & 0.179 & 0.178 & 0.282 & 0.179 & 0.285 & 0.291 & $0.632 * *$ & 0.313 \\
\hline Education4 & 0.168 & 0.178 & 0.264 & 0.179 & 0.266 & 0.293 & $0.602 *$ & 0.314 \\
\hline Education5 & 0.172 & 0.179 & 0.264 & 0.179 & 0.250 & 0.299 & $0.595^{*}$ & 0.320 \\
\hline Education6 & 0.186 & 0.179 & 0.266 & 0.180 & 0.265 & 0.303 & $0.567 *$ & 0.324 \\
\hline Education7 & 0.139 & 0.179 & 0.236 & 0.179 & 0.185 & 0.304 & 0.508 & 0.326 \\
\hline Education8 & 0.138 & 0.180 & 0.220 & 0.180 & 0.167 & 0.312 & 0.463 & 0.332 \\
\hline Non-manual & $0.058 * * *$ & 0.022 & 0.021 & 0.022 & $0.125 * * *$ & 0.042 & $0.106^{* *}$ & 0.048 \\
\hline Salespersons & $0.057 * *$ & 0.024 & 0.039 & 0.024 & $0.091 * *$ & 0.039 & $0.081 * *$ & 0.040 \\
\hline Labourers & -0.021 & 0.024 & -0.003 & 0.024 & -0.067 & 0.042 & -0.055 & 0.044 \\
\hline Age & $-0.036 * * *$ & 0.005 & $-0.035^{* * *}$ & 0.005 & $-0.058 * * *$ & 0.008 & $-0.056 * * *$ & 0.008 \\
\hline $\mathrm{Age}^{2}$ & $0.046^{* * *}$ & 0.006 & $0.045^{* * *}$ & 0.006 & $0.073 * * *$ & 0.009 & $0.071 * * *$ & 0.009 \\
\hline Nationality & $-0.104 * * *$ & 0.026 & $-0.113^{* * *}$ & 0.026 & $-0.142 * * *$ & 0.046 & $-0.129 * * *$ & 0.046 \\
\hline Population2 & $-0.064 * * *$ & 0.019 & $-0.063 * * *$ & 0.019 & $-0.113^{* * *}$ & 0.030 & $-0.117 * * *$ & 0.031 \\
\hline Population3 & $-0.126^{* * *}$ & 0.023 & $-0.124 * * *$ & 0.023 & $-0.210^{* * *}$ & 0.038 & $-0.222 * * *$ & 0.038 \\
\hline Population4 & $-0.121 * * *$ & 0.019 & $-0.121 * * *$ & 0.019 & $-0.202 * * *$ & 0.030 & $-0.216^{* * *}$ & 0.030 \\
\hline Population5 & $-0.295 * * *$ & 0.027 & $-0.296^{* * *}$ & 0.027 & -0.474 & 0.045 & -0.489 & 0.046 \\
\hline Hours & $-0.008 * * *$ & 0.001 & $-0.008 * * *$ & 0.001 & $-0.013 * * *$ & 0.001 & -0.012 & 0.001 \\
\hline Income 2 & $0.163 * * *$ & 0.019 & $0.150 * * *$ & 0.019 & $0.301 * * *$ & 0.034 & 0.298 & 0.036 \\
\hline Income3 & $0.234 * * *$ & 0.021 & $0.218^{* * *}$ & 0.021 & $0.428 * * *$ & 0.043 & 0.423 & 0.045 \\
\hline Income4 & $0.273 * * *$ & 0.025 & $0.254 * * *$ & 0.025 & $0.505 * * *$ & 0.060 & 0.499 & 0.061 \\
\hline Income5 & $0.385 * * *$ & 0.031 & $0.369 * * *$ & 0.031 & $0.685 * * *$ & 0.079 & 0.672 & 0.078 \\
\hline Permanent & $0.178 * * *$ & 0.018 & $0.170 * * *$ & 0.018 & $0.303 * * *$ & 0.029 & 0.300 & 0.030 \\
\hline Training & $0.272 * * *$ & 0.014 & $0.263 * * *$ & 0.014 & $0.448 * * *$ & 0.026 & 0.444 & 0.027 \\
\hline Industry & $0.117 * * *$ & 0.042 & $0.105^{* *}$ & 0.042 & $0.231 * * *$ & 0.067 & 0.233 & 0.068 \\
\hline Construction & $0.127 * * *$ & 0.043 & $0.110^{* *}$ & 0.043 & $0.244 * * *$ & 0.070 & 0.238 & 0.071 \\
\hline Services & $0.224 * * *$ & 0.041 & $0.206^{* * *}$ & 0.041 & $0.392 * * *$ & 0.066 & 0.379 & 0.067 \\
\hline Tenure & $-0.013 * * *$ & 0.002 & $-0.013 * * *$ & 0.002 & $-0.016^{* * *}$ & 0.004 & -0.016 & 0.004 \\
\hline Tenure $^{2}$ & $0.020 * * *$ & 0.006 & $0.019 * * *$ & 0.006 & $0.019 *$ & 0.010 & 0.020 & 0.010 \\
\hline First & $0.054 * * *$ & 0.016 & $0.051 * * *$ & 0.016 & $0.090 * * *$ & 0.028 & 0.089 & 0.028 \\
\hline Union & $-0.120 * * *$ & 0.017 & $-0.119 * * *$ & 0.017 & $-0.221 * * *$ & 0.028 & -0.222 & 0.028 \\
\hline Firm_size2 & $-0.099 * * *$ & 0.019 & $-0.098 * * *$ & 0.019 & $-0.147 * * *$ & 0.031 & -0.158 & 0.032 \\
\hline Firm_size3 & $-0.131 * * *$ & 0.021 & $-0.128 * * *$ & 0.021 & $-0.192 * * *$ & 0.035 & -0.188 & 0.035 \\
\hline Firm_size4 & $-0.139 * * *$ & 0.019 & $-0.134 * * *$ & 0.019 & $-0.208 * * *$ & 0.031 & -0.205 & 0.032 \\
\hline Married & $0.064 * * *$ & 0.016 & $0.063 * * *$ & 0.016 & $0.105 * * *$ & 0.025 & 0.097 & 0.026 \\
\hline Children 0-2 & $-0.033^{*}$ & 0.019 & -0.031 & 0.019 & -0.045 & 0.032 & -0.038 & 0.032 \\
\hline Children 3-5 & -0.009 & 0.019 & -0.007 & 0.019 & -0.009 & 0.031 & 0.010 & 0.032 \\
\hline Children6-14 & $0.034 * * *$ & 0.012 & $0.034 * * *$ & 0.012 & $0.046^{* *}$ & 0.019 & 0.054 & 0.019 \\
\hline Year 2 & $0.113^{* * *}$ & 0.029 & $0.135^{* * *}$ & 0.029 & $0.169 * * *$ & 0.054 & 0.161 & 0.055 \\
\hline
\end{tabular}




\begin{tabular}{|c|c|c|c|c|c|c|c|c|}
\hline Year 3 & $0.204 * * *$ & 0.029 & $0.215 * * *$ & 0.029 & $0.269 * * *$ & 0.052 & 0.250 & 0.052 \\
\hline Year 4 & $0.249 * * *$ & 0.029 & $0.257 * * *$ & 0.029 & $0.348 * * *$ & 0.052 & 0.333 & 0.051 \\
\hline /cut_1_1 & -3.165 & 0.208 & -3.184 & 0.208 & & & & \\
\hline /cut_1_2 & -2.971 & 0.208 & -2.987 & 0.208 & & & & \\
\hline /cut_1_3 & -2.723 & 0.207 & -2.737 & 0.207 & & & & \\
\hline /cut_1_4 & -2.434 & 0.207 & -2.444 & 0.207 & & & & \\
\hline /cut_1_5 & -2.138 & 0.206 & -2.145 & 0.207 & & & & \\
\hline /cut_1_6 & -1.569 & 0.206 & -1.571 & 0.206 & & & & \\
\hline /cut_1_7 & -1.098 & 0.206 & -1.096 & 0.206 & & & & \\
\hline /cut_1_8 & -0.448 & 0.206 & -0.443 & 0.206 & & & & \\
\hline /cut_1_9 & 0.402 & 0.206 & 0.411 & 0.206 & & & & \\
\hline /cut_1_10 & 0.946 & 0.206 & 0.956 & 0.206 & & & & \\
\hline $\log \mathrm{L}$ & \multicolumn{2}{|c|}{-47599} & \multicolumn{2}{|c|}{-47469} & \multirow{2}{*}{\multicolumn{2}{|c|}{0.10}} & \multirow{2}{*}{\multicolumn{2}{|c|}{0.11}} \\
\hline $\mathrm{R}^{2}$ adjusted & & & & & & & & \\
\hline
\end{tabular}


Tabla 4. Over-education and Over-qualification coefficients for all facets of job satisfaction

\begin{tabular}{|c|c|c|c|c|c|c|c|c|c|c|c|c|}
\hline & \multicolumn{7}{|c|}{ Ordered probit } & \multicolumn{5}{|c|}{ IV } \\
\hline & \multicolumn{2}{|c|}{ Over-education } & \multicolumn{6}{|c|}{ Over-qualification } & \multicolumn{2}{|c|}{ Over-education } & \multicolumn{2}{|c|}{ Over-qualification } \\
\hline & & & Unadjus & ted & Appare & & Genui & & & & & \\
\hline Job satisfaction & $-0.548 * * *$ & 0.018 & $-0.224 * * *$ & 0.018 & $-0.451 * * *$ & 0.022 & $-0.781 * * *$ & 0.025 & $-0.639 * * *$ & 0.236 & $-0.238 * * *$ & 0.086 \\
\hline Firm's work organisation & $-0.377 * * *$ & 0.017 & $-0.13 * * *$ & 0.018 & $-0.335 * * *$ & 0.022 & $-0.493 * * *$ & 0.025 & -0.190 & 0.308 & -0.048 & 0.113 \\
\hline Promotion prospect & $-0.335 * * *$ & 0.018 & $-0.299 * * *$ & 0.019 & $-0.281 * * *$ & 0.023 & $-0.544 * * *$ & 0.026 & 0.437 & 0.462 & -0.149 & 0.168 \\
\hline $\begin{array}{l}\text { Recognition of the work/relations with } \\
\text { management }\end{array}$ & $-0.373 * * *$ & 0.018 & $-0.150 * * *$ & 0.019 & $-0.321 * * *$ & 0.022 & $-0.510^{* * *}$ & 0.025 & 0.079 & 0.322 & 0.059 & 0.118 \\
\hline Activity in work & $-0.512 * * *$ & 0.018 & $-0.191 * * *$ & 0.018 & $-0.402 * * *$ & 0.022 & $-0.748 * * *$ & 0.025 & $-1.145^{* * *}$ & 0.245 & $-0.451 * * *$ & 0.089 \\
\hline Personal development / Self-fulfilment & $0.595 * * *$ & 0.018 & $-0.204 * * *$ & 0.018 & $-0.473 * * *$ & 0.022 & $-0.856 * * *$ & 0.025 & $-2.182 * * *$ & 0.280 & $-0.823 * * *$ & 0.101 \\
\hline Level of freedom/ autonomy at work & $-0.324 * * *$ & 0.017 & $-0.111 * * *$ & 0.018 & $-0.270 * * *$ & 0.022 & $-0.446 * * *$ & 0.025 & $-1.729 * * *$ & 0.313 & $-0.632 * * *$ & 0.114 \\
\hline Participation in decisions related to job tasks & $-0.394 * * *$ & 0.018 & $-0.195 * * *$ & 0.018 & $-0.316^{* * *}$ & 0.022 & $-0.590 * * *$ & 0.025 & $-2.327 * * *$ & 0.374 & $-0.828 * * *$ & 0.135 \\
\hline Workday/ Working day & $-0.221 * * *$ & 0.017 & $-0.123 * * *$ & 0.018 & $-0.166 * * *$ & 0.022 & $-0.348 * * *$ & 0.025 & 0.461 & 0.316 & -0.184 & 0.116 \\
\hline Hour flexibility & $-0.226 * * *$ & 0.018 & $-0.170 * * *$ & 0.018 & $-0.158 * * *$ & 0.022 & $-0.393 * * *$ & 0.025 & -0.353 & 0.433 & -0.125 & 0.159 \\
\hline Duration of work breaks & $-0.233 * * *$ & 0.017 & $-0.136 * * *$ & 0.018 & $-0.184 * * *$ & 0.022 & $-0.359 * * *$ & 0.025 & 0.544 & 0.379 & 0.209 & 0.139 \\
\hline Paid vacations & $-0.246^{* * *}$ & 0.018 & $-0.153 * * *$ & 0.018 & $-0.202 * * *$ & 0.022 & $-0.373 * * *$ & 0.025 & 0.098 & 0.323 & 0.086 & 0.119 \\
\hline Job stability & $-0.222 * * *$ & 0.018 & $-0.108 * * *$ & 0.018 & $-0.169 * * *$ & 0.022 & $-0.342 * * *$ & 0.025 & -0.070 & 0.319 & -0.004 & 0.117 \\
\hline Firm's provided training & $-0.413 * * *$ & 0.018 & $-0.365 * * *$ & 0.019 & $-0.331 * * *$ & 0.023 & $-0.699 * * *$ & 0.026 & -0.611 & 0.409 & $-0.247 *$ & 0.150 \\
\hline Earnings/ pay/ salary & $-0.392 * * *$ & 0.017 & $-0.184 * * *$ & 0.018 & $-0.359 * * *$ & 0.022 & $-0.520 * * *$ & 0.025 & 0.142 & 0.306 & 0.086 & 0.113 \\
\hline Firm's provided social support & $-0.22 * * *$ & 0.019 & $-0.230 * * *$ & 0.021 & $-0.166^{* * *}$ & 0.024 & $-0.399 * * *$ & 0.028 & 0.503 & 0.437 & 0.233 & 0.162 \\
\hline Health and safety at work & $-0.272 * * *$ & 0.017 & $-0.129 * * *$ & 0.018 & $-0.213 * * *$ & 0.022 & $-0.409 * * *$ & 0.025 & 0.125 & 0.304 & 0.059 & 0.111 \\
\hline
\end{tabular}


Table 5. Exogeneity tests

\begin{tabular}{|c|c|c|c|c|c|c|c|c|c|c|c|c|c|c|}
\hline & \multicolumn{2}{|c|}{ LogL oprobit } & \multicolumn{6}{|c|}{ IV over-education } & \multicolumn{6}{|c|}{ IV over-qualification } \\
\hline & Over-edu & Over-qua & $\mathrm{R} 2$ & Durbin & Wu Hausman & $\mathrm{R} 2$ & $\mathrm{~F}$ & Shea's $\mathrm{R}^{2}$ & $\mathrm{R} 2$ & Durbin & Nu Hausman & R2 & $\mathrm{F}$ & Shea's $\mathrm{R}^{2}$ \\
\hline Job satisfaction & & & & 1.281 & 1.279 & & 376.547 & & & 5.031 & 5.023 & & 442.002 & \\
\hline & -47599 & -47469 & 0.100 & $(0.258)$ & $(0.258)$ & 0.014 & $(0.0000)$ & 0.014 & 0.109 & $(0.025)$ & $(0.025)$ & 0.145 & $(0.000)$ & 0.016 \\
\hline Firm's work organisation & & & & 4.206 & 4.199 & & 376.547 & & & 8.951 & 8.937 & & 442.002 & \\
\hline & -53221 & -53183 & 0.057 & $(0.040)$ & $(0.040)$ & 0.014 & $(0.0000)$ & 0.014 & 0.054 & $(0.003)$ & $(0.003)$ & 0.145 & $(0.000)$ & 0.016 \\
\hline Promotion prospect & & & & 9.810 & 9.794 & & 376.547 & & & 18.427 & 18.404 & & 442.002 & \\
\hline & -52673 & -52524 & 0.073 & $(0.002)$ & $(0.002)$ & 0.014 & $(0.0000)$ & 0.014 & 0.072 & $(0.000)$ & $(0.000)$ & 0.145 & $(0.000)$ & 0.016 \\
\hline Recognition of the work/ & & & & 8.510 & 8.497 & & 376.547 & & & 15.701 & 15.7680 & & 442.002 & \\
\hline relations with management & -50480 & -50430 & 0.045 & $(0.004)$ & $(0.004)$ & 0.014 & $(0.0000)$ & 0.014 & 0.040 & $(0.000)$ & $(0.000)$ & 0.145 & $(0.000)$ & 0.016 \\
\hline Activity in work & & & & 1.011 & 1.009 & & 376.547 & & & 0.074 & 0.074 & & 442.002 & \\
\hline & -47401 & -47286 & 0.081 & $(0.315)$ & $(0.315)$ & 0.014 & $(0.0000)$ & 0.014 & 0.100 & $(0.785)$ & $(0.785)$ & 0.145 & $(0.000)$ & 0.016 \\
\hline Personal development / Self- & & & & 12.554 & 12.538 & & 376.547 & & & 6.942 & 6.931 & & 442.002 & \\
\hline fulfilment & -49970 & -49833 & 0.078 & $(0.000)$ & $(0.000)$ & 0.014 & $(0.0000)$ & 0.014 & 0.112 & $(0.008)$ & $(0.008)$ & 0.145 & $(0.000)$ & 0.016 \\
\hline Level of freedom/ autonomy at & & & & 10.800 & 10.785 & & 376.547 & & & 6.800 & 6.789 & & 442.002 & \\
\hline work & -52136 & -52101 & 0.051 & $(0.001)$ & $(0.001)$ & 0.014 & $(0.0000)$ & 0.014 & 0.069 & $(0.009)$ & $(0.009)$ & 0.145 & $(0.000)$ & 0.016 \\
\hline Participation in & & & & 12.367 & 12.350 & & 376.547 & & & 5.227 & 5.218 & & 442.002 & \\
\hline related to job tasks & -54343 & -54251 & 0.071 & $(0.000)$ & $(0.000)$ & 0.014 & $(0.0000)$ & 0.014 & 0.102 & $(0.022)$ & $(0.022)$ & 0.145 & $(0.000)$ & 0.016 \\
\hline Workday /Working day & & & & 9.877 & 9.863 & & 376.547 & & & 15.509 & 15.490 & & 442.002 & \\
\hline & -52936 & -52896 & 0.030 & $(0.002)$ & $(0.002)$ & 0.014 & $(0.0000)$ & 0.014 & 0.026 & $(0.000)$ & $(0.000)$ & 0.145 & $(0.000)$ & 0.016 \\
\hline Hour flexibility & & & & 0.615 & 0.614 & & 376.547 & & & 2.777 & 2.773 & & 442.002 & \\
\hline & -57426 & -57355 & 0.035 & $(0.433)$ & $(0.433)$ & 0.014 & $(0.0000)$ & 0.014 & 0.037 & $(0.096)$ & $(0.096)$ & 0.145 & $(0.000)$ & 0.016 \\
\hline Duration of work breaks & & & & 9.967 & 9.953 & & 376.547 & & & 15.165 & 15.146 & & 442.002 & \\
\hline & -55739 & -55696 & 0.014 & $(0.002)$ & $(0.002)$ & 0.014 & $(0.0000)$ & 0.014 & 0.011 & $(0.000)$ & $(0.000)$ & 0.145 & $(0.000)$ & 0.016 \\
\hline Paid vacations & & & & 4.165 & 4.158 & & 376.547 & & & 9.852 & 9.837 & & 442.002 & \\
\hline & -51171 & -51122 & 0.105 & $(0.041)$ & $(0.041)$ & 0.014 & $(0.0000)$ & 0.014 & 0.102 & $(0.002)$ & $(0.002)$ & 0.145 & $(0.000)$ & 0.016 \\
\hline Job stability & & & & 2.157 & 2.154 & & 376.547 & & & 5.349 & 5.340 & & 442.002 & \\
\hline & -50105 & -50073 & 0.244 & $(0.142)$ & $(0.142)$ & 0.014 & $(0.0000)$ & 0.014 & 0.245 & $(0.021)$ & $(0.021)$ & 0.145 & $(0.000)$ & 0.016 \\
\hline Firm's provided training & & & & 1.661 & 1.658 & & 376.547 & & & 7.266 & 7.254 & & 442.002 & \\
\hline & -53185 & -52938 & 0.203 & $(0.198)$ & $(0.198)$ & 0.014 & $(0.0000)$ & 0.014 & 0.212 & $(0.007)$ & $(0.007)$ & 0.145 & $(0.000)$ & 0.016 \\
\hline Earnings/ pay/ salary & & & & 10.524 & 10.509 & & 376.547 & & & 19.445 & 19.423 & & 442.002 & \\
\hline & -53891 & -53827 & 0.119 & $(0.001)$ & $(0.001)$ & 0.014 & $(0.0000)$ & 0.014 & 0.114 & $(0.000)$ & $(0.000)$ & 0.145 & $(0.000)$ & 0.016 \\
\hline Firm's provided social support & & & & 6.298 & 6.287 & & 376.547 & & & 13.373 & 13.353 & & 442.002 & \\
\hline & -47724 & -46640 & 0.135 & $(0.012)$ & $(0.012)$ & 0.014 & $(0.0000)$ & 0.014 & 0.128 & $(0.000)$ & $(0.000)$ & 0.145 & $(0.000)$ & 0.016 \\
\hline Health and safety at work & & & & 5.446 & 5.437 & & 376.547 & & & 10.089 & 10.074 & & 442.002 & \\
\hline & -51904 & -51860 & 0.028 & $(0.020)$ & $(0.020)$ & 0.014 & $(0.0000)$ & 0.014 & 0.025 & $(0.002)$ & $(0.002)$ & 0.145 & $(0.000)$ & 0.016 \\
\hline
\end{tabular}


Table A1: Variable definitions and average values (2007-2010).

\begin{tabular}{|c|c|c|}
\hline \multirow{2}{*}{\multicolumn{3}{|c|}{$\begin{array}{l}\text { Variable } \quad \text { Definition } \\
\text { Personal characteristics }\end{array}$}} \\
\hline & & \\
\hline Gender & 1: man, 0: woman & 0.594 \\
\hline Age & Age in years & 40.459 \\
\hline $\mathrm{Age}^{2} / 100$ & Age squared divided by 100 & 17.528 \\
\hline Nationality & 1: Spanish, 0: foreign & 0.872 \\
\hline Education1 & Pre-primary & 3.15 \\
\hline Education2 & Primary & 15.56 \\
\hline Education3 & Lower Secondary & 21.24 \\
\hline Education4 & Upper secondary & 10.11 \\
\hline Education5 & Vocational short & 10.50 \\
\hline Education6 & Vocational long/ & 13.28 \\
\hline Education7 & Short Bachelor & 10.76 \\
\hline Education8 & Long Bachelor and above & 14.40 \\
\hline Population1 & City size lower than 10,000 inhabitants & 0.202 \\
\hline Population2 & City size between 10,001 and 50,000 inhabitants & 0.278 \\
\hline Population3 & City size between 50,001 and 100,000 inhabitants & 0.120 \\
\hline Population4 & City size between 100,001 and $1,000,000$ inhabitants & 0.317 \\
\hline Population5 & City size higher than $1,000,000$ inhabitants & 0.082 \\
\hline Married & 1: live in couple & 0.674 \\
\hline Children 0-2 & 1: children $0-2$ years old & 0.113 \\
\hline Children 3-5 & 1: children $3-5$ years old & 0.108 \\
\hline Children 6-14 & 1: children $6-14$ years old & 0.305 \\
\hline \multicolumn{3}{|c|}{ Job characteristics } \\
\hline Hours worked & Number of hours worked per week & 39.573 \\
\hline Income 1 & Up to 1,000 euro per month (net) & 0.351 \\
\hline Income2 & Between 1,001 and 1,200 euro per month (net) & 0.237 \\
\hline Income3 & Between 1,201 and 1,600 euro per month (net) & 0.228 \\
\hline Income4 & Between 1,601 and 2,100 euro per month (net) & 0.108 \\
\hline Income5 & More than 2,100 euro per month (net) & 0.076 \\
\hline Permanent & Permanent contract: 1 , fixed-term contract: 0 & 0.769 \\
\hline Training & The firm has provided some training in the last 12 months & 0.446 \\
\hline Agriculture & The employee works in Agriculture & 0.035 \\
\hline Industry & The employee works in Industry & 0.229 \\
\hline Construction & The employee works in Construction & 0.128 \\
\hline Services & The employee works in Services & 0.608 \\
\hline Manual & Qualified workers in agriculture, qualified monitoring and monitored workers & 0.291 \\
\hline Non-manual & Qualified worker (managers, professionals, technicians, and clerical workers) & 0.432 \\
\hline Salespersons & Unqualified workers in services (sales, personal services,...) & 0.158 \\
\hline Labourers & Unqualified workers in other branches (labourers, drivers,...) & 0.119 \\
\hline Tenure & Number of years in the same firm & 8.966 \\
\hline Tenure $^{2} / 100$ & Tenure squared divided by 100 & 2.318 \\
\hline First & 1: This is the first job & 0.208 \\
\hline Union & The employee is unionised & 0.166 \\
\hline Firm_size1 & Firm size lower than 10 employees & 0.287 \\
\hline Firm_size2 & Firm size between 11 and 50 employees & 0.248 \\
\hline Firm_size3 & Firm size between 51 and 250 employees & 0.168 \\
\hline Firm_size4 & Firm size higher than 250 employees & 0.297 \\
\hline
\end{tabular}




\section{DOCUMENTOS DE TRABAJO \\ Facultad de Economía y Empresa \\ Universidad de Zaragoza \\ Depósito Legal Z-1411-2010. ISSN 2171-6668}

2002-01: "Evolution of Spanish Urban Structure During the Twentieth Century". Luis Lanaspa, Fernando Pueyo y Fernando Sanz. Department of Economic Analysis, University of Zaragoza.

2002-02: "Una Nueva Perspectiva en la Medición del Capital Humano". Gregorio Giménez y Blanca Simón. Departamento de Estructura, Historia Económica y Economía Pública, Universidad de Zaragoza.

2002-03: "A Practical Evaluation of Employee Productivity Using a Professional Data Base". Raquel Ortega. Department of Business, University of Zaragoza.

2002-04: "La Información Financiera de las Entidades No Lucrativas: Una Perspectiva Internacional". Isabel Brusca y Caridad Martí. Departamento de Contabilidad y Finanzas, Universidad de Zaragoza.

2003-01: "Las Opciones Reales y su Influencia en la Valoración de Empresas". Manuel Espitia y Gema Pastor. Departamento de Economía y Dirección de Empresas, Universidad de Zaragoza.

2003-02: "The Valuation of Earnings Components by the Capital Markets. An International Comparison". Susana Callao, Beatriz Cuellar, José Ignacio Jarne and José Antonio Laínez. Department of Accounting and Finance, University of Zaragoza.

2003-03: "Selection of the Informative Base in ARMA-GARCH Models". Laura Muñoz, Pilar Olave and Manuel Salvador. Department of Statistics Methods, University of Zaragoza.

2003-04: "Structural Change and Productive Blocks in the Spanish Economy: An Imput-Output Analysis for 1980-1994”. Julio Sánchez Chóliz and Rosa Duarte. Department of Economic Analysis, University of Zaragoza.

2003-05: "Automatic Monitoring and Intervention in Linear Gaussian State-Space Models: A Bayesian Approach". Manuel Salvador and Pilar Gargallo. Department of Statistics Methods, University of Zaragoza.

2003-06: "An Application of the Data Envelopment Analysis Methodology in the Performance Assessment of the Zaragoza University Departments". Emilio Martín. Department of Accounting and Finance, University of Zaragoza.

2003-07: "Harmonisation at the European Union: a difficult but needed task". Ana Yetano Sánchez. Department of Accounting and Finance, University of Zaragoza.

2003-08: "The investment activity of spanish firms with tangible and intangible assets". Manuel Espitia and Gema Pastor. Department of Business, University of Zaragoza. 
2004-01: "Persistencia en la performance de los fondos de inversión españoles de renta variable nacional (1994-2002)". Luis Ferruz y María S. Vargas. Departamento de Contabilidad y Finanzas, Universidad de Zaragoza.

2004-02: "Calidad institucional y factores político-culturales: un panorama internacional por niveles de renta". José Aixalá, Gema Fabro y Blanca Simón. Departamento de Estructura, Historia Económica y Economía Pública, Universidad de Zaragoza.

2004-03: "La utilización de las nuevas tecnologías en la contratación pública". José Ma Gimeno Feliú. Departamento de Derecho Público, Universidad de Zaragoza.

2004-04: "Valoración económica y financiera de los trasvases previstos en el Plan Hidrológico Nacional español". Pedro Arrojo Agudo. Departamento de Análisis Económico, Universidad de Zaragoza. Laura Sánchez Gallardo. Fundación Nueva Cultura del Agua.

2004-05: "Impacto de las tecnologías de la información en la productividad de las empresas españolas". Carmen Galve Gorriz y Ana Gargallo Castel. Departamento de Economía y Dirección de Empresas. Universidad de Zaragoza.

2004-06: "National and International Income Dispersión and Aggregate Expenditures". Carmen Fillat. Department of Applied Economics and Economic History, University of Zaragoza. Joseph Francois. Tinbergen Institute Rotterdam and Center for Economic Policy Resarch-CEPR.

2004-07: "Targeted Advertising with Vertically Differentiated Products". Lola Esteban and José M. Hernández. Department of Economic Analysis. University of Zaragoza.

2004-08: "Returns to education and to experience within the EU: are there differences between wage earners and the self-employed?". Inmaculada García Mainar. Department of Economic Analysis. University of Zaragoza. Víctor M. Montuenga Gómez. Department of Business. University of La Rioja

2005-01: "E-government and the transformation of public administrations in EU countries: Beyond NPM or just a second wave of reforms?". Lourdes Torres, Vicente Pina and Sonia Royo. Department of Accounting and Finance.University of Zaragoza

2005-02: "Externalidades tecnológicas internacionales y productividad de la manufactura: un análisis sectorial”. Carmen López Pueyo, Jaime Sanau y Sara Barcenilla. Departamento de Economía Aplicada. Universidad de Zaragoza.

2005-03: "Detecting Determinism Using Recurrence Quantification Analysis: Three Test Procedures". María Teresa Aparicio, Eduardo Fernández Pozo and Dulce Saura. Department of Economic Analysis. University of Zaragoza.

2005-04: "Evaluating Organizational Design Through Efficiency Values: An Application To The Spanish First Division Soccer Teams". Manuel Espitia Escuer and Lucía Isabel García Cebrián. Department of Business. University of Zaragoza.

2005-05: "From Locational Fundamentals to Increasing Returns: The Spatial Concentration of Population in Spain, 1787-2000". María Isabel Ayuda. Department of 
Economic Analysis. University of Zaragoza. Fernando Collantes and Vicente Pinilla. Department of Applied Economics and Economic History. University of Zaragoza.

2005-06: "Model selection strategies in a spatial context". Jesús Mur and Ana Angulo. Department of Economic Analysis. University of Zaragoza.

2005-07: "Conciertos educativos y selección académica y social del alumnado". María Jesús Mancebón Torrubia. Departamento de Estructura e Historia Económica y Economía Pública. Universidad de Zaragoza. Domingo Pérez Ximénez de Embún. Departamento de Análisis Económico. Universidad de Zaragoza.

2005-08: "Product differentiation in a mixed duopoly". Agustín Gil. Department of Economic Analysis. University of Zaragoza.

2005-09: "Migration dynamics, growth and convergence". Gemma Larramona and Marcos Sanso. Department of Economic Analysis. University of Zaragoza.

2005-10: "Endogenous longevity, biological deterioration and economic growth". Marcos Sanso and Rosa María Aísa. Department of Economic Analysis. University of Zaragoza.

2006-01: "Good or bad? - The influence of FDI on output growth. An industry-level analysis“. Carmen Fillat Castejón. Department of Applied Economics and Economic History. University of Zaragoza. Julia Woerz. The Vienna Institute for International Economic Studies and Tinbergen Institute, Erasmus University Rotterdam.

2006-02: "Performance and capital structure of privatized firms in the European Union". Patricia Bachiller y $\mathrm{M}^{\mathrm{a}}$ José Arcas. Departamento de Contabilidad y Finanzas. Universidad de Zaragoza.

2006-03: "Factors explaining the rating of Microfinance Institutions". Begoña Gutiérrez Nieto and Carlos Serrano Cinca. Department of Accounting and Finance. University of Saragossa, Spain.

2006-04: "Libertad económica y convergencia en argentina: 1875-2000". Isabel Sanz Villarroya. Departamento de Estructura, Historia Económica y Economía Pública. Universidad de Zaragoza. Leandro Prados de la Escosura. Departamento de $\mathrm{H}^{\mathrm{a}} \mathrm{e}$ Instituciones Ec. Universidad Carlos III de Madrid.

2006-05: "How Satisfied are Spouses with their Leisure Time? Evidence from Europe*”. Inmaculada García, José Alberto Molina y María Navarro. University of Zaragoza.

2006-06: "Una estimación macroeconómica de los determinantes salariales en España (1980-2000)". José Aixalá Pastó y Carmen Pelet Redón. Departamento de Estructura, Historia Económica y Economía Pública. Universidad de Zaragoza.

2006-07: "Causes of World Trade Growth in Agricultural and Food Products, 1951 2000”. Raúl Serrano and Vicente Pinilla. Department of Applied Economics and Economic History, University of Zaragoza, Gran Via 4, 50005 Zaragoza (Spain).

2006-08: "Prioritisation of patients on waiting lists: a community workshop approach". Angelina Lázaro Alquézar. Facultad de Derecho, Facultad de Económicas. University of 
Zaragoza. Zaragoza, Spain. Begoña Álvarez-Farizo. C.I.T.A.- Unidad de Economía. Zaragoza, Spain

2007-01: "Deteminantes del comportamiento variado del consumidor en el escenario de Compra". Carmén Berné Manero y Noemí Martínez Caraballo. Departamento de Economía y Dirección de Empresas. Universidad de Zaragoza.

2007-02: "Alternative measures for trade restrictiveness. A gravity approach". Carmen Fillat \& Eva Pardos. University of Zaragoza.

2007-03: "Entrepreneurship, Management Services and Economic Growth". Vicente Salas Fumás \& J. Javier Sánchez Asín. Departamento de Economía y Dirección de Empresas. University of Zaragoza.

2007-04: "Equality versus Equity based pay systems and their effects on rational altruism motivation in teams: Wicked masked altruism". Javier García Bernal \& Marisa Ramírez Alerón. University of Zaragoza.

2007-05: "Macroeconomic outcomes and the relative position of Argentina's Economy: 1875-2000”. Isabel Sanz Villarroya. University of Zaragoza.

2008-01: "Vertical product differentiation with subcontracting". Joaquín Andaluz Funcia. University of Zaragoza.

2008-02: "The motherwood wage penalty in a mediterranean country: The case of Spain” Jose Alberto Molina Chueca \& Victor Manuel Montuenga Gómez. University of Zaragoza.

2008-03: "Factors influencing e-disclosure in local public administrations". Carlos Serrano Cinca, Mar Rueda Tomás \& Pilar Portillo Tarragona. Departamento de Contabilidad y Finanzas. Universidad de Zaragoza.

2008-04: "La evaluación de la producción científica: hacia un factor de impacto neutral". José María Gómez-Sancho y María Jesús Mancebón-Torrubia. Universidad de Zaragoza.

2008-05: "The single monetary policy and domestic macro-fundamentals: Evidence from Spain“. Michael G. Arghyrou, Cardiff Business School and Maria Dolores Gadea, University of Zaragoza.

2008-06: "Trade through fdi: investing in services". Carmen Fillat-Castejón, University of Zaragoza, Spain; Joseph F. Francois. University of Linz, Austria; and CEPR, London \& Julia Woerz, The Vienna Institute for International Economic Studies, Austria.

2008-07: "Teoría de crecimiento semi-endógeno vs Teoría de crecimiento completamente endógeno: una valoración sectorial". Sara Barcenilla Visús, Carmen López Pueyo, Jaime Sanaú. Universidad de Zaragoza.

2008-08: "Beating fiscal dominance. The case of spain, 1874-1998". M. D. Gadea, M. Sabaté \& R. Escario. University of Zaragoza.

2009-01: "Detecting Intentional Herding: What lies beneath intraday data in the Spanish stock market" Blasco, Natividad, Ferreruela, Sandra (Department of Accounting 
and Finance. University of Zaragoza. Spain); Corredor, Pilar (Department of Business Administration. Public University of Navarre, Spain).

2009-02: "What is driving the increasing presence of citizen participation initiatives?". Ana Yetano, Sonia Royo \& Basilio Acerete. Departamento de Contabilidad y Finanzas. Universidad de Zaragoza.

2009-03: "Estilos de vida y "reflexividad" en el estudio del consumo: algunas propuestas". Pablo García Ruiz. Departamento de Psicología y Sociología. Universidad de Zaragoza.

2009-04: "Sources of Productivity Growth and Convergence in ICT Industries: An Intertemporal Non-parametric Frontier Approach". Carmen López-Pueyo and Mª Jesús Mancebón Torrubia. Universidad de Zaragoza.

2009-05: "Análisis de los efectos medioambientales en una economía regional: una aplicación para la economía aragonesa”. Mónica Flores García y Alfredo J. Mainar Causapé. Departamento de Economía y Dirección de Empresas. Universidad de Zaragoza.

2009-06: "The relationship between trade openness and public expenditure. The Spanish case, 1960-2000". M ${ }^{\text {a }}$ Dolores Gadea, Marcela Sabate y Estela Saenz. Department of Applied Economics. School of Economics. University of Economics.

2009-07: "Government solvency or just pseudo-sustainability? A long-run multicointegration approach for Spain". Regina Escario, María Dolores Gadea, Marcela Sabaté. Applied Economics Department. University of Zaragoza.

2010-01: "Una nueva aproximación a la medición de la producción científica en revistas JCR y su aplicación a las universidades públicas españolas”. José María GómezSancho, María Jesús Mancebón Torrubia. Universidad de Zaragoza

2010-02: "Unemployment and Time Use: Evidence from the Spanish Time Use Survey". José Ignacio Gimenez-Nadal, University of Zaragoza, José Alberto Molina, University of Zaragoza and IZA, Raquel Ortega, University of Zaragoza.

2011-01: "Universidad y Desarrollo sostenible. Análisis de la rendición de cuentas de las universidades del G9 desde un enfoque de responsabilidad social”. Dr. José Mariano Moneva y Dr. Emilio Martín Vallespín, Universidad de Zaragoza.

2011-02: "Análisis Municipal de los Determinantes de la Deforestación en Bolivia." Javier Aliaga Lordeman, Horacio Villegas Quino, Daniel Leguía (Instituto de Investigaciones Socio-Económicas. Universidad Católica Boliviana), y Jesús Mur (Departamento de Análisis Económico. Universidad de Zaragoza)

2011-03: "Imitations, economic activity and welfare". Gregorio Giménez. Facultad de Ciencias Económicas y Empresariales. Universidad de Zaragoza.

2012-01: "Selection Criteria for Overlapping Binary Models". M. T Aparicio and I. Villanúa. Department of Economic Analysis, Faculty of Economics, University of Zaragoza

2012-02: "Sociedad cooperativa y socio cooperativo: propuesta de sus funciones objetivo". Carmen Marcuello y Pablo Nachar-Calderón. Universidad de Zaragoza 
2012-03: "Is there an environmental Kuznets curve for water use? A panel smooth transition regression approach". Rosa Duarte (Department of Economic Analysis), Vicente Pinilla (Department of Applied Economics and Economic History) and Ana Serrano (Department of Economic Analysis). Faculty of Economics and Business Studies, Universidad de Zaragoza

2012-04: "Análisis Coste-Beneficio de la introducción de dispositivos ahorradores de agua. Estudio de un caso en el sector hotelero". Barberán Ramón, Egea Pilar, Gracia-deRentería Pilar y Manuel Salvador. Facultad de Economía y Empresa. Universidad de Zaragoza.

2013-01: "The efficiency of Spanish mutual funds companies: A slacks - based measure approach". Carlos Sánchez González, José Luis Sarto and Luis Vicente. Department of Accounting and Finance. Faculty of Economics and Business Studies, University of Zaragoza.

2013-02: "New directions of trade for the agri-food industry: a disaggregated approach for different income countries, 1963-2000". Raúl Serrano (Department of Business Administration) and Vicente Pinilla (Department of Applied Economics and Economic History). Universidad de Zaragoza.

2013-03: "Socio-demographic determinants of planning suicide and marijuana use among youths: are these patterns of behavior causally related?". Rosa Duarte, José Julián Escario and José Alberto Molina. Department of Economic Analysis, Universidad de Zaragoza.

2014-01: "Análisis del comportamiento imitador intradía en el mercado de valores español durante el periodo de crisis 2008-2009”. Alicia Marín Solano y Sandra Ferreruela Garcés. Facultad de Economía y Empresa, Universidad de Zaragoza.

2015-01: "International diversification and performance in agri-food firms". Raúl Serrano, Marta Fernández-Olmos and Vicente Pinilla. Facultad de Economía y Empresa, Universidad de Zaragoza.

2015-02: "Estimating income elasticities of leisure activities using cross-sectional categorized data". Jorge González Chapela. Centro Universitario de la Defensa de Zaragoza.

2015-03: "Global water in a global world a long term study on agricultural virtual water flows in the world". Rosa Duarte, Vicente Pinilla and Ana Serrano. Facultad de Economía y Empresa, Universidad de Zaragoza.

2015-04: "Activismo local y parsimonia regional frente a la despoblación en Aragón: una explicación desde la economía política”. Luis Antonio Sáez Pérez, María Isabel Ayuda y Vicente Pinilla. Facultad de Economía y Empresa, Universidad de Zaragoza.

2015-05: "What determines entepreneurial failure: taking advantage of the institutional context". Lucio Fuentelsaz, Consuelo González-Gil y Juan P. Maicas. University of Zaragoza.

2015-06: "Factores macroeconómicos que estimulan el emprendimiento. Un análisis para los países desarrollados y no desarrollados". Beatriz Barrado y José Alberto Molina. Universidad de Zaragoza. 
2015-07: "Emprendedores y asalariados en España: efectos de la situación financiera familiar y diferencias en salarios". Jorge Velilla y José Alberto Molina. Universidad de Zaragoza.

2016-01: "Time spent on cultural activities at home in Spain: Differences between wage-earners and the self-employed". José Alberto Molina, Juan Carlos Campaña and Raquel Ortega. University of Zaragoza.

2016-02: "Human resource management practices and organizational performance. The mediator role of immaterial satisfaction in Italian Social Cooperatives". Silvia Sacchetti (University of Stirling), Ermanno C. Tortia (University of Trento) and Francisco J. López Arceiz (University of Zaragoza).

2016-03: "Exploration, exploitation and innovation performance: Disentangling environmental dynamism". Pilar Bernal (University of Zaragoza), Juan P. Maicas (University of Zaragoza) and Pilar Vargas (University of La Rioja).

2016-04: "Las relaciones comerciales contemporáneas de Aragón con Cataluña: de la complementariedad al modelo intraindustrial". Luis Germán Zubero (University of Zaragoza) y Vicente Pinilla (University of Zaragoza).

2016-05: "La demanda de agua urbana para actividades productivas. Un análisis con microdatos". Pilar Gracia de Rentería, Ramón Barberán y Jesús Mur. Universidad de Zaragoza.

2017-01: "Testing for breaks in the weighting matrix". Ana Angulo (University of Zaragoza), Peter Burridge (University of York) and Jesús Mur (University of Zaragoza).

2017-02: "Los determinantes del autosuministro de agua para actividades productivas en un entorno urbano. El caso del municipio de Zaragoza". Pilar Gracia de Rentería, Ramón Barberán y Jesús Mur. Universidad de Zaragoza.

2017-03: "Subjective educational mismatch and signalling in Spain". Inmaculada García-Mainar and Víctor M. Montuenga-Gómez. University of Zaragoza.

2017-04: "Collaborative networks and export intensity in family firms: a quantile regression approach". Raúl Serrano, Isabel Acero-Fraile and Natalia Dejo-Oricain. University of Zaragoza.

2017-05: "Over-qualification and dimensions of job satisfaction". Inmaculada GarcíaMainar and Victor M. Montuenga-Gómez. University of Zaragoza. 